\title{
MULTIPLE CEREBRAL TUBERCULOMAS WITHOUT FOCAL NEUROLOGICAL DEFICIT IN AN IMMUNOCOMPETENT ADULT NIGERIAN: A CASE REPORT
}

\author{
Okokhere O. Peter, ${ }^{1,2}$ Akhuemokhan I. Kennedy, ${ }^{1,2}$ Wahab W. Kolawole, ${ }^{3}$ \\ Akhigbe O. Theophilus, ${ }^{4}$ Akpede O. George ${ }^{5}$ \\ ${ }^{1}$ College of Medicine, Ambrose Alli university, Ekpoma, Edo State, Nigeria \\ ${ }^{2}$ Department of Medicine, Irrua Specialist Teaching Hospital, P.M.B 8, Irrua, Edo State, Nigeria \\ ${ }^{3}$ Division of Neurology, Department of Medicine, University of Ilorin Teaching Hospital, Nigeria \\ ${ }^{4}$ Department of Radiology, Irrua Specialist Teaching Hospital, P.M.B 08, Irrua, Edo State, Nigeria \\ ${ }^{5}$ Department of Paediatrics, Irrua Specialist Teaching Hospital, P.M.B 08, Irrua, Edo State, Nigeria
}

Primljen/Received 23. 09. 2016. god.

Abstract: Multiple cerebral tuberculomas complicating miliary tuberculosis are a rare occurrence. It is rarer still for multiple cerebral tuberculomas to present without focal neurological deficits. We report the case of a middle-aged Nigerian male with the co-morbidity of miliary tuberculosis and multiple cerebral tuberculomas who presented without focal neurological deficits, but had complete resolution of symptoms and signs following a 6-month course of antituberculous therapy. This unique case emphasizes the need for a high index of suspicion in the diagnosis of atypical presentations of cerebral tuberculomas, while also further illustrating the place of computed tomographic scan of the brain in diagnosis. The case also illustrates the place of therapeutic trial in management.

Keywords: Multiple cerebral tuberculomas,index of suspicion, therapeutic trial, Nigeria.

\section{INTRODUCTION}

Worldwide, tuberculosis (TB) remains a serious public health problem $(1,2,3)$. Challenges in management occur, especially with the advent of the HIV/AIDS scourge and emergence of multi-drug resistant TB (3, 4). Although the causative organism, Mycobacterium tuberculosis,can affect many organs, it most commonly affects the lungs $(1,5)$. However, central nervous system (CNS) involvement in the form of tuberculous meningitis, tuberculous abscess or tuberculomas is not uncommon, especially in immune-compromised individuals (1). Tuberculous meningitis is the most
Prihvaćen/Accepted 20. 11. 2016. god.

common CNS manifestation of TB. While an isolated cerebral tuberculoma is rare (6), multiple cerebral tuberculomas associated with pulmonary miliary TB is rarer still (7).

Most cases of cerebral tuberculomas present with focal neurological signs (5-8) and have been reported from various regions of the world (5-13). However, in spite of the high burden of tuberculosis in the West African sub-region which is made worse by the scourge of HIV/AIDS and multi-drug resistance, there is a paucity of information on cerebral tuberculomas from the sub-region. We report the case of an immune-competent Nigerian male with multiple cerebral tuberculomas associated with pulmonary miliary TB, who presented without focal neurological signs, and recovered fully following anti-tuberculosis therapy.

\section{CASE REPORT}

A 56-year-old farmer was referred to the Department of Medicine, Irrua Specialist Teaching Hospital, Irrua, Edo State, Nigeria, in July, 2000 on account of intermittent fever and neck pain of 4 months' duration, weight loss and reduced appetite of 2 months' duration, urinary incontinence of 1 week's duration and altered level of consciousness of a few hours' duration. He had associated headache and tremulousness but no blurring of vision, photophobia, vomiting or seizures. There was also no history of weakness in any of the limbs. In the 3 months before presentation, he was noticed to have a non-productive cough that was not asso- 
ciated with pleurisy or haemoptysis. He had paralytic poliomyelitis in childhood with residual right lower limb deformity. He neither smoked cigarette nor drank alcohol and had no history of contact with an individual known to have pulmonary tuberculosis. The rest of the history was not remarkable.

Physical examination showed a chronically ill-looking middle-aged man, who was drowsy and responded to commands and questions inappropriately. $\mathrm{He}$ was febrile with an axillary temperature of $38.8^{\circ} \mathrm{C}$ and had signs of some dehydration. He was neither pale nor jaundiced. There were no enlarged peripheral lymph nodes. His pupils were round, normal-sized and briskly reactive to bright light while the optic fundi were normal bilaterally. There was neck stiffness, but he had no other signs of meningeal irritation such as Kernig's and Brudzinski's signs. Aside from the right lower limb deformity probably due to childhood paralytic poliomyelitis, he had no focal neurological deficits. His pulse rate was 112 beats per minute, and supine blood pressure 120/80 mmHg. The heart sounds were normal. The respiratory rate was 30 cycles per minute. Aside from reduced air entry in the lungs globally, the chest examination was unremarkable, as was the abdominal examination.

He had a postero-anterior chest radiograph which showed widespread miliary nodules, suggestive of pulmonary military TB. A clinical impression of pulmonary miliary TB complicated by TB meningitis was made. Cerebrospinal fluid (CSF) analysis, including microscopy and culture and smear for acid and alcohol fast bacilli (AAFB) were normal. Cough was not productive of sputum, so analysis of sputum for mycobacteria could not be done. The erythrocyte sedimentation rate (ESR) was $30 \mathrm{~mm} / \mathrm{hr}$. The complete blood count, serum electrolytes, urea and creatinine, blood glucose
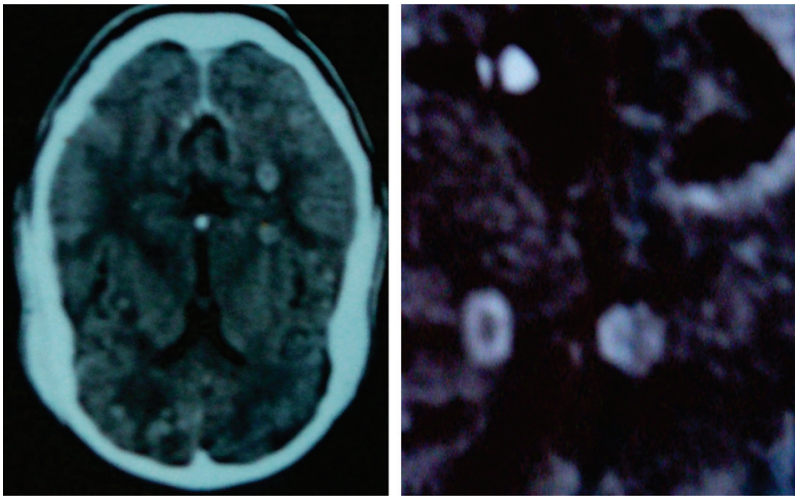

Figure 1a (left) shows pre-treatment CT Brain scan showing multiple ring-enhanced lesions suggestive of cerebral tuberculomas. Figure $\mathbf{1 b}$ (right) shows caseation in lesions in a magnified image of the CT Brain scan
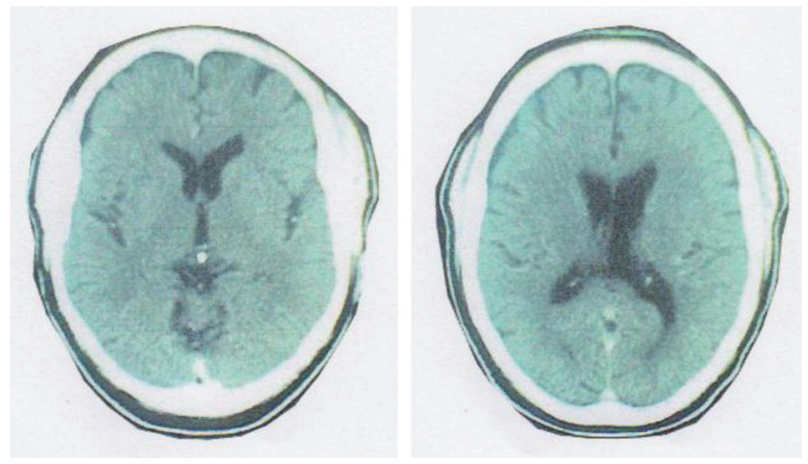

Figures $2 \boldsymbol{a}$ and $2 \boldsymbol{b}$. 9 years post-treatment CT scan showing complete resolution of tuberculoma lesions

and liver function tests were within normal limits. No malaria parasites were seen on blood smear, and HIV I and II screens were negative. A computerised tomographic (CT) scan of the brain showed numerous, irregular, contrast-enhanced, small, widespread brain lesions with minimal surrounding oedema and no evidence of shift of midline brain structure or cerebral collection (Figures 1a and $1 b$ ). The findings were suggestive of cerebral tuberculomas.

With the above history, and chest radiographic and $\mathrm{CT}$ brain scan findings, a diagnosis of pulmonary miliary TB with multiple cerebral tuberculomas was made and the patient commenced on a 6-month course of anti-tuberculosis therapy. The initial phase of 8 weeks was with 4 drugs (rifampicin, isoniazid, ethambutol and pyrazinamide) followed by a continuation phase of 16 weeks with 2 drugs (rifampicin and isoniazid) in standard daily doses under the DOTS strategy.

The patient made remarkable clinical progress as evidenced by weight gain and the resolution of fever and other symptoms, and was discharged home, after 26 days on admission, with no neurological sequelae. On follow up for more than sixteen years, he remained healthy and free from neurological sequelae, and has been able to continue with farming. For financial reasons, he was unable to repeat the CT brain scan soon after treatment. However, a repeat CT brain scan 9 years after treatment showed complete resolution of the cerebral tuberculomas (Figures $2 \mathrm{a}$ and $2 \mathrm{~b}$ ), thus confirming the response to therapy.

\section{DISCUSSION}

Cerebral tuberculoma is an important differential diagnosis in patients with focal neurological signs in areas endemic for TB $(7,8)$, not only in immune-compromised patients $(14,15)$, but also in immune-competent patients with miliary pulmonary $\mathrm{TB}$, when TB meningitis has been excluded.

CNS tuberculosis can present clinically in many ways, but tuberculous meningitis is the commonest 
manifestation (1). While tuberculomas can present without meningeal involvement $(5,6)$, as was the case with our patient, most often, however, brain TB lesions commonly complicate TB meningitis (12). Cerebral tuberculomas have been reported in $8-17 \%$ of patients with TB meningitis $(12,16)$.

CNS TB is not uncommon in developing countries (16), but multiple cerebral tuberculomas are rare (15), especially in association with miliary pulmonary TB (7) in immune-competent patients. Multiple cerebral tuberculomas are more often associated with miliary TB in children (17) although some reports in adults also show this association $(5,14)$.

The clinical features of cerebral tuberculoma depend on the size and location of the tuberculoma, and are similar to the neurological presentation of many other space occupying lesions. Aside from TB, the differential diagnoses of space occupying lesions, which causes may involve the lungs in immunocompetent individuals in developing countries, include pyogenic abscess, cysticercosis, and toxoplasmosis. Lymphoma is another possible differential but the chest radiograph usually shows intrathoracic lymphadenopathy when the lung parenchyma is involved.

Our patient presented with drowsiness, urinary incontinence and inappropriate response to command, features that could have been due to encephalopathy from a myriad of causes, but are not typical of a space-occupying lesion. The lack of focal neurological signs in our patient is in contrast to reported cases $(5-8,14)$.

CT brain scan is useful in the diagnosis of cerebral tuberculoma $(7,13,15,16)$. However, since some other space occupying lesions may have similar features $(6$, 8 ), the findings may be non-specific for intracranial tuberculomas, except when the 'target sign', thought to be characteristic of cerebral tuberculoma, is present (18). Therefore advanced MRI techniques, which are scarce in many developing countries, may be required to differentiate cerebral tuberculoma from other space occupying lesions, if invasive procedures are to be avoided.

Although the definitive diagnosis of TB remains the isolation of Mycobacterium tuberculosis, culture and/or Ziehl-Nielson (AAFB) staining of tissues from excision or biopsy may not identify the organism in some cases (7). Thus, even at autopsy or with surgical biopsy specimens, the isolation of Mycobacterium tuberculosis is possible in only $50 \%$ of cases (19). However, most of the developing countries which bear the greatest burden of tuberculosis lack adequate resources and often times have to rely on good clinical judgement. As typified by our patient, a high index of suspicion is important in areas of high TB endemicity, as some patients with cerebral tuberculomas may not have signs of focal neurological deficit at presentation.

Treatment of intracranial tuberculoma may be surgical when the lesions are large and few, and are causing focal neurological deficits, as in the cases reported by Muin and Zurin (7), or medical when the lesions are small and numerous like in our case and that of Innocenti et al (5) and Gasparetto et al (14). The complete resolution of lesions on medical therapy alone which has been documented previously $(14,20,21)$, is supported by our report.

\section{CONCLUSION}

Our case report demonstrates the presentation of multiple cerebral tuberculomas without focal neurological deficits and the need for a high index of suspicion. Cranial CT scan is invaluable in unravelling the aetiology of such enigmatic cases where patients show signs of diffuse brain parenchymal involvement but no lateralizing signs. Our case also supports the place of therapeutic trial, with response to therapy used retrospectively to confirm the diagnosis of intra-cerebral tuberculosis.

\section{Conflict of interest}

The authors have no conflict of interest to declare.

\section{Funding}

The Management of Irrua Specialist Teaching Hospital, Irrua, Nigeria, graciously provided the funds for the post- treatment CT Scan of the patient.

\section{Acknowledgements}

We thank the Management of Irrua Specialist Teaching Hospital for providing the grant that made it possible to have a repeat CT scan for the patient.

We are grateful to the patient for giving his permission for the publication of this paper.
Abbreviations
DOTS - Directly Observed Therapy Short course
HIV - Human Immunodeficiency Virus
AIDS - Acquired Immune Deficiency Syndrome
MRI - Magnetic Resonance Imaging 


\section{Sažetak}

\section{MULTIPLI CEREBRALNI TUBERKULOMI BEZ FOKALNIH NEUROLOŠKIH ISPADA KOD IMUNOKOMPROMITOVANE ODRASLE OSOBE U NIGERIJI — PRIKAZ SLUCAJA}

Okokhere O. Peter, ${ }^{1,2}$ Akhuemokhan I. Kennedy, ${ }^{1,2}$ Wahab W. Kolawole, ${ }^{3}$ Akhigbe O. Theophilus, ${ }^{4}$ Akpede O. George ${ }^{5}$

${ }^{1}$ College of Medicine, Ambrose Ali university, Ekpoma, Edo State, Nigeria ${ }^{2}$ Department of Medicine, Irrua Specialist Teaching Hospital, P.M.B 8, Irrua, Edo State, Nigeria

${ }^{3}$ Division of Neurology, Department of Medicine, University of Ilorin Teaching Hospital, Nigeria

${ }^{4}$ Department of Radiology, Irrua Specialist Teaching Hospital, P.M.B 08, Irrua, Edo State, Nigeria

${ }^{5}$ Department of Paediatrics, Irrua Specialist Teaching Hospital, P.M.B 08, Irrua, Edo State, Nigeria

Multipli cerebrali tuberkulomi predstavljaju jednu od komplikacija miljarne tuberkuloze i izuzetno se retko javljaju. Još je ređi slučaj pojave milijarnih moždanih tuberkuloma bez fokalnog neurološkog deficita. Ovom studijom mi prikazujemo slučaj srednjovečnog Nigerijca sa milijarnom tuberkulozom i multiplim cerebralnim tuberkulomima, koji su se javili bez neuroloških ispada, uz kompletno povlačenje simptoma i znakova bolesti nakon

\section{REFERENCES}

1. Raviglione MC, O'Brien RJ. Tuberculosis. In: Longo DL, Fauci AS, Kasper DL, Hauser SJ, Jameson JL, and Loscalzo J (eds): Harrison's Principles of Internal Medicine, $18^{\text {th }}$ ed. New York, MacGraw Hill, 2012; p 1340-59.

2. Global Tuberculosis control: Surveillance, Planning and Financing. Geneva: WHO, 2006. WHO/HTM/TB 2006.362.

3. Corbett EL, Watt CJ, Walker N, et al. The growing burden of tuberculosis: global trends and interactions with HIV epidemic. Arch Intern Med. 2003; 163(9): 1009-21.

4. Raviglione MC, Smith IM. XDR tuberculosis-Implications for global public health. N Engl J Med. 2007; 356(7): $656-9$.

5. Innocenti R, Deg'IInnocenti L, Fronzaroti C, Ferrante F, Corradi F. Radiological miliary patterns of cerebral tuberculosis. Arch Neurology. 2005; 62(1): 153-54.

6. Catano JC. Images in clinical medicine. Cerebral Tuberculoma. N Eng J Med. 2007; 357(21): 2166.

7. Muin I.A, Zurin A.R. Pulmonary miliary tuberculosis with intracerebral tuberculous granulomas-report of two cases. British journal of neurology. 1998; 12(6): 585-87.

8. Ogbole GI, Bassey OS, Okolo CA, Ukperi SO, Ogunseyinde AO. Testicular tuberculosis presenting with metastatic intracranial tuberculomas: a case report. J Med Case Rep. 2011; $5: 100$.

9. Sulsu HT, Bozbuga M, Bayuidir C. Cerebral tuberculoma mimicking high grade glial tumour. Turk Neurosurg. 2011; 21(3): 427-9.

10. Sahaiu-Srivastava S, Jones B. Brainstem tuberculoma in the immunocompetent: case report and literature review. ClinNeurolNeurosurg. 2008; 110(3): 302-4.

\section{Correspondence to / Autorzakorespondenciju}

Dr. Peter O. Okokhere

Department of Medicine

Irrua Specialist Teaching Hospital

P.M.B 8, Irrua, Edo State, Nigeria

E mail: okokherep@gmail.com

Telephone: +2348037275351 šestomesečne antituberkulozne terapije. Ovaj jedinstven slučaj daje na značaju povišenom indeksu sumnje na tuberkulozu kod atipične prezentacije simptoma, kao i ulozi metoda vizuelizacije u postavljanju dijagnoze, kao što je kompjuterska tomografija (CT). Slučaj takođe prikazuje značajnu ulogu terapije u daljem lečenju pacijenta.

Ključne reči: multipli cerebralni tuberkulomi, indeks sumnje, terapeutski slučaj, Nigerija.

11. Thornell L, Pendle S, Sacks L. Clinical and radiological features of South African patients with cerebral tuberculomas of the brain. Clin Infect Dis. 2000; 31(2): 619-20.

12. Cagatay AA, OzsutH, Gulec L, et al. Tuberculous meningitis in adults-experience from Turkey. Inter J Clin Pract. 2004; 58 (5): 469-73.

13. Dennison P, Rajakaruna G. Cerebral Tuberculoma. Thorax. 2006; 61(10); 922.

14. Gasparetto E L, Tazoniero P, Neto AC. Disseminated tuberculosis in a pregnant woman presenting with numerous brain tuberulomas: case report. Arq Neuropsiquiatr. 2003; 61(3-B): 855-8.

15. Whiteman MLH. Neuroimaging of central nervous tuberculosis in HIV infected patients. Neuroimaging Clin N Am. 1997; 7(2): 199-214.

16. Hosoglu S, Geyik MF, Balik I et al. Predictors of outcome in patients with tuberculous meningitis. Int J Tuberc Lung Dis. 2002; 6(1)1: 64-70.

17. Ravenscroft A, Schoeman JF, Donald PR. Tuberculous granulomas in childhood tuberculous meningitis: radiological features and course. J Trop Paed. 2001; 47(1): 5-12.

18. Del Brutto O, Mosquera A.Brainstem tuberculoma mimicking glioma: the role of anti-tuberculous drugs as a diagnostic tool. Neurology. 1999; 52(1): 210-1.

19. DeAngelis LM. Intracranialtuberculoma: case report and review of the literature. Neurology. 1998: 31(9): 1133-36.

20. Monteino R, Carneiron JC, Costa C, Duarte R. Cerebral tuberculomas-a clinical challenge. Respir Med Case Rep. 2013; 9: 34-7.

21. Garg RK, Sharma R, Kar AM, et al. Neurological complications of military tuberculosis. ClinNeurolNeurosurg. 2010; 112(3): 188-92. 